\title{
Immunogenicity characterization of mononucleated cells originated from umbillical cord blood
}

\author{
Caroline T. Sardjono, ${ }^{1,2}$ Melina Setiawan, ${ }^{1}$ Frans D. Suyatna, ${ }^{3}$ Irvanyuni Japutri, ${ }^{1}$ Boenjamin Setiawan, ${ }^{4}$ Ferry Sandra ${ }^{1}$ \\ ${ }^{1}$ Stem Cell and Cancer Institute. Jl. A. Yani no 2. Pulo Mas, Jakarta 13210, Indonesia \\ ${ }^{2}$ Microbiology Department, Faculty of Medicine, Maranatha Christian University, Bandung 40164, Indonesia \\ ${ }^{3}$ Department of Pharmacology and Therapeutics, Medical Faculty, University of Indonesia, Jakarta, Indonesia \\ ${ }^{4}$ Kalbe Farma Tbk. Jl. Let. Jend. Suprapto Kav 4. Cempaka Putih, Jakarta 10510, Indonesia
}

\begin{abstract}
Abstrak
Tujuan Sel punca yang diisolasi dari darah tali pusat diketahui merupakan populasi sel mononuklear yang terdapat dalam darah tali pusat. Hingga saat ini, telah banyak laporan mengenai penggunaan sel tipe ini sebagai alternatif transplantasi sel punca secara alogenik. Berdasarkan laporan beberapa hasil studi klinis, sel darah tali pusat dapat ditoleransi sekalipun pada kasus ketidakcocokan human leukocyte antigen (HLA) pada beberapa alel dengan jumlah kasus graft versus host reaction yang rendah. Penelitian ini mengkarakterisasi profil imunogenisitas sel mononuklear darah tali pusat yang diketahui banyak mengandung sel punca, melalui analisis reaksi alogenik yang ditimbulkannya dan dibandingkan dengan reaksi terhadap sel yang berasal dari darah tepi.
\end{abstract}

Metode Aloreaktifitas dari darah tali pusat dianalisis dengan pemeriksaan mixed lymphocyte reaction (MLR) dilanjutkan dengan deteksi IFN- $\gamma$ yang disekresikan ke dalam medium. Tipe HLA sel donor dan efektor diperiksa dengan pemeriksaan HLA berbasis PCR untuk menentukan reaktivitas alogenik. Lebih lanjut, tingkat ekspresi HLA kelas I dan II ditentukan dengan teknik flowcytometry menggunakan antibodi monoklonal terhadap kedua molekul tersebut.

Hasil Dalam medium kultur MLR dengan sel darah tali pusat, ditemukan bahwa titer IFN- $\gamma$ yang terdeteksi jauh lebih rendah daripada hasil MLR sel darah tepi. Hal ini menunjukan bahwa stimulasi alogenik yang ditimbulkan oleh sel darah tali pusat lebih rendah daripada darah tepi, sekaligus mengindikasikan rendahnya potensi rejeksi tipe sel tersebut. Hasil pemeriksaan tipe HLA menunjukkan bahwa hanya terdapat 1-3 kecocokan alel dari 8 alel pasangan sel yang digunakan dalam esai MLR. Lebih lanjut, ditemukan bahwa ekspresi molekul HLA kelas I pada sel darah tali pusat sangat rendah dan hanya sebagian kecil sel yang mengekspresikan HLA kelas II.

Kesimpulan Studi ini mendemonstrasikan rendahnya imunogenisitas sel darah tali pusat melalui rendahnya IFN- $\gamma$ yang disekresikan pada pemeriksaan MLR dan juga melalui rendahnya ekspresi molekul HLA kelas I serta lebih sedikitnya sel yang mengekspresikan HLA kelas II pada UCBMC. Hasil penelitian ini diharapkan akan menambah pemahaman mengenai pemanfaatan darah tali pusat sebagai sumber alternatif sel punca pada transplantasi alogenik. (Med J Indones 2010; 19:14-20)

\begin{abstract}
Aim Umbilical cord blood mononucleated (UCBMC) cells has been shown to be the stem cells originated from umbilical cord blood. To date, UCBMC has been introduced as an alternative source for stem cells used in autologous and allogeneic transplantations. Several clinical studies have demonstrated that UCBMCs required less stringent selection for HLA matches between donor and recipient with less cases of graft versus host reaction. In this study, UCBMCs are known to contain many stem cells, were characterized and compared to peripheral blood for their immunogenic profile.

Method To elucidate the potential of UCBMC alloreactivity, mixed lymphocyte reaction (MLR) assay was performed. The donor and effectors cells were HLA-typed using PCR method to determine their alloreactivity. Further, to distinguish the level of HLA class I and II expression flowcytometry was done using monoclonal antibodies against those molecules. All the analyse were carried out on UCBMCs and peripheral blood mononucleated cells (PBMCs).

Results The result of MLR assay showed that there was less IFN- $\gamma$ secretion detected in the co-cultured medium in the presence of UCBMCs compared to PBMCs counterpart, indicating less possible rejection of UCBMC. Further, we found that there were only 1-3 alleles of HLA match (out of 8 alleles) among the PBMCs and UCBMCs. By using flowcytometry assay, we could further demonstrate lower HLA Class I expression level with less amount of HLA Class II expressing cells in UCBMC compared to those in PBMCs.

Conclusion These findings clearly demonstrate the low immunogenicity of UCBMCs, based on the low level of secreted IFN- $\gamma$ in the MLR assay, low expression level of HLA Class I, and small population of HLA Class II expressing cells. The outcomes from this study would raise a better understanding in the usage of umbilical cord blood as an alternative source of stem cells for allogeneic transplantation. (Med J Indones 2010; 19:14-20)
\end{abstract}

Key words: umbilical cord blood, immunogenicity, stem cell

Correspondence e-mail to: carolinesardjono@yahoo.com 
Allogeneic stem cell transplantation has been reported to be a potential therapy used to treat hematological malignancy and several degenerative diseases. ${ }^{1-4}$ Many groups have reported the application of stem cells from several sources including bone marrow, peripheral blood, and umbilical cord blood in clinical applications. ${ }^{5-6}$ However, the major limitation in the usage of bone marrow $(\mathrm{BM})$ and peripheral blood (PB) stem cells for allogeneic transplantation lies in the difficulties to find compatible donors. Human leukocyte antigen (HLA) which is also referred to as major histocompatibility complex (MHC) plays an important role in intercellular recognition and discrimination between self and non-self antigen. Thus, in many stem cell applications, HLA matching between donor and recipient is essential for successful treatment.

Umbilical cord blood (UCB) has been introduced as an alternative source of stem cells for allogeneic transplantation since the successful transplantation for Fanconi's anemia treatment. ${ }^{7,8}$ To date, UCB stem cells have been used for more than 6000 transplants to treat many types of malignant and non malignant disorders. ${ }^{9}$ UCB seems more tolerant of HLA mismatches, with less risk of graft versus host reaction. ${ }^{10}$ It was reported that fewer requirements were needed for absolute matching using umbilical cord blood (UCB) for transplantation due to less maturity of stem cells in cord blood compared to stem cells from other sources. ${ }^{11-17}$ However, the characterization of immunogenicity profile of umbilical cord blood mononucleated cells (UCBMCs) as the most dominant population in UCB has never been reported before. In this study, the immunogenicity of UCBMC was assessed and compared to peripheral blood mononucleated cells (PBMCs) using in vitro assays including mixed lymphocyte reaction (MLR), PCRbased HLA typing and determination of HLA expression using flowcytometry, to get a better understanding on the low immunogenicity of UCBMC.

\section{METHODS}

\section{Peripheral blood and umbilical cord blood mononucleated cells isolation}

All protocols were reviewed and approved by the Stem Cell and Cancer Institute Institutional Review Board prior to the study (Proposal number 11/IRB/ $\mathrm{SCI} / \mathrm{KF} / 2008$ ). Peripheral blood were obtained with informed consent from donors voluntarily agreeing to donate their blood. Umbilical cord blood was obtained with informed consent from mothers voluntarily agreeing to donate their umbilical cord blood collected immediately after giving birth. Collected blood samples were transferred to Stem Cell and Cancer Institute laboratory and processed within 48 hours. Since it was known that stem cells are a population in mononucleated cells found in peripheral and umbilical cord blood, stem cells isolation was performed using protocol for mononucleated cells isolation by gradient centrifugation using Ficoll-Paque (GE Healthcare). Isolated cells were counted and cryopreserved using $10 \%$ Dimethyl Sulfoxide (DMSO) in M-199 medium (Gibco) added with 30\% Fetal Bovine Serum (Gibco). Cells were then aliquoted into cryovials and stored at $-196^{\circ} \mathrm{C}$ by immersion in the liquid nitrogen until further use.

\section{Mixed lymphocyte reaction (MLR)}

MLR assay was done by co-culturing donor cells (UCBMCs or PBMCs) with recipient cells (PBMCs) at $37^{\circ} \mathrm{C}$ in a humidified incubator with $5 \% \mathrm{CO}_{2}$. UCBMCs or PBMCs as responder cells were stimulated for 36 hours in 24-well plate. Cells were cultured using RPMI 1640 medium supplemented with $7 \%$ FBS at $1.3 \mathrm{x}$ $10^{5}$ cells $/ \mathrm{cm}^{2}$ density. After 36 hours, supernatant was harvested followed by enzyme-linked immunosorbent assay (ELISA) assay to detect IFN- $\gamma$ secretion. Briefly, 96-well ELISA plates were coated with $50 \quad 1$ per well (of $5 \mathrm{mg} / \mathrm{ml}$ ) of mouse anti- human IFN- $\gamma$ (Biosources, Invitrogen) as capturing antibody for 6 hours at $4^{\circ} \mathrm{C}$ followed by blocking with $2 \%$ bovine serum albumin (BSA) in phosphate buffer saline overnight. The medium were serially diluted and added to each well. The IFN- $\gamma$ bound was detected by biotinylated mouse monoclonal antibodi against human IFN- $\gamma$ (Biosources, Invitrogen) as detecting antibody. Subsequently, streptavidin conjugated with horse raddish peroxide (HRP) to develope the substrate (2.2 azino-di-ethy benathiazoline sulfate/ABTS) (Boehringer Mannheim, Rockville, MD). Color changes were measured by an ELISA plate reader at wave length of $405 \mathrm{~nm}$. Concentrations of the IFN- $\gamma$ were calculated using a standard curve of purified human IFN- $\gamma$ (Roche) with known concentration.

\section{HLA Typing}

The cells used in the MLR were HLA typed using a PCR-based typing method to determine typing of HLA Class I (HLA-A, HLA-B) and HLA Class II (HLA-DRB1, HLA-DQB1) (ABDRDQ SSP UniTray ${ }^{\circledR}$ Invitrogen 78500). The DNA samples were isolated 
from the cells using DNA isolation Kit (High pure PCR Template preparation Kit, Roche). The DNA were then subsequently used in the PCR amplification process on the provided 96-well tray with specific primer sets according to the manufacture recommendation. The PCR products were analyzed on $2.5 \%$ agarose gel stained with ethidium bromide $(0.5 \mu \mathrm{g} / \mathrm{ml})$. Positive lanes were determined as the presence of bands of $220 \mathrm{bp}$ or $240 \mathrm{bp}$ depending on the primer sets.

\section{Detection of HLA class I and class II}

HLA class I (HLA-ABC) and class II (HLA-DP/DQ/ DR) molecules have important roles in determining immunogenicity profile of UCBMC. Flowcytometry assay (FACSCalibur, BD Biosciences) was used to determine the expression levels of HLA class I molecules on UCBMCs. The detection was done using anti-HLA class I mAb conjugated with Phycoerythrin (Abcam 43545), while cell expressing HLA class II molecules were also characterized with mAb HLA class II conjugated with PE (Abcam 23901). Isotype mIgG2a-PE (Becton Dickinson 349053) was used as a control to determine the background staining. In this assay, PBMCs were used as a comparison for levels of HLA molecule expressions.

\section{RESULTS}

\section{IFN- $\gamma$ secretion in MLR}

Allogeneic stimulation by PBMC was observed through high titer of IFN- $\gamma$ released in supernatant (102.34 \pm $21.03 \mathrm{U} / \mathrm{ml}$ ) of co-cultured PBMCs from different donors in MLR assay (Figure 1). In contrast, only $23.46 \pm 4.19 \mathrm{U} / \mathrm{ml}$ of IFN- $\gamma$ was detected in supernatant with the presence of UCBMCs in the co-culture with PBMCs. Based on this result, UCBMCs significantly elicit less allogeneic stimulation compared to PBMCs counterpart in MLR assay ( $\mathrm{p}$ value $<0.001$ ).

\section{HLA Typing}

HLA typing analysis was done on the cells used in the MLR studies. Figure 2 shows a typical gel image following PCR reaction to determine the HLA types. A single band at $780 \mathrm{bp}$ was observed as an internal control within each lane, showing that the PCR reaction was working optimally. The positive lanes represented as visualized bands with the size of $220 \mathrm{bp}$ or $240 \mathrm{bp}$ depending on the primer sets for specific alleles. The HLA types of the cells (PBMCs and UCBMCs) used in the MLR studies were as shown on Table 1.

\section{Detection of HLA class I and class II levels of expression}

Flowcytometry analysis was performed using antiHLA class I antibody conjugated to fluorescein. The degree of fluorescence corresponded to the levels of molecules expression (Figure 3). It was found that UCBMCs demonstrated significantly lower expression of HLA Class I molecules $(37.6 \pm 3.65 \%)$ compared to the PBMCs counterpart $(87.8 \pm 2.28 \%)$ Figure 3; $\mathrm{p}$-value $<0.001$. HLA Class I is a molecule responsible for antigen recognition by cytotoxic $\mathrm{T}$ cell $\left(\mathrm{CD}^{+} \mathrm{Tc}\right)$ therefore less expression of this molecule indicates the less capability of allogenic recognition of UCBMC. Using the flowcytometry analysis, it was found that among the UCBMCs, there were less cells expressing HLA Class II molecule $(7.20 \% \pm 4.32$ from the total cells), compared to PBMC $27.14 \% \pm 7.54$; p-value $<$ 0.001 (Figure 4).

Table 1. HLA types of UCBMCs and PBMCs used in the MLR studies and degrees of compatibility according to number of allele matched

\begin{tabular}{|c|c|c|c|c|c|c|c|c|c|}
\hline \multirow{3}{*}{ Sample ID } & \multicolumn{4}{|c|}{ Class I } & \multicolumn{4}{|c|}{ Class II } & \multirow{3}{*}{$\begin{array}{l}\text { Allele } \\
\text { matched }\end{array}$} \\
\hline & \multicolumn{2}{|c|}{ HLA-A } & \multicolumn{2}{|c|}{ HLA- B } & \multicolumn{2}{|c|}{ HLA-DRB1 } & \multicolumn{2}{|c|}{ HLA-DQB1 } & \\
\hline & $\begin{array}{l}\text { Allele } 1 \\
\end{array}$ & Allele 2 & Allele 1 & Allele 2 & Allele 1 & Allele 2 & Allele 1 & Allele 2 & \\
\hline UCBMC 1 & $A * 14$ & $\mathrm{~A}^{* 14}$ & $B * 45$ & $\mathrm{~B} * 20$ & DRB1*12 & DRB1*12 & DQB1*03 & DQB1*03 & 30 \\
\hline PBMC 1 & $A * 14$ & $A * 14$ & $B * 32$ & $B * 50$ & DRB $1 * 03$ & DRB $1 * 09$ & DQB $1 * 02$ & DQB1*03 & 5 \\
\hline UCBMC 1 & $A * 14$ & $A^{*} 14$ & $B * 45$ & $B * 20$ & $\mathrm{DRB} 1 * 12$ & $\mathrm{DRB} 1 * 12$ & $\mathrm{DQB} 1 * 03$ & DQB1*03 & 0 \\
\hline PBMC 2 & $A * 32$ & $A * 33$ & $B * 15$ & $B * 23$ & DRB $1 * 12$ & DRB1*15 & DQB1*08 & DQB1*09 & 1018 \\
\hline UCBMC 2 & $A * 02$ & $A * 34$ & $B * 40$ & $B * 54$ & DRB $1 * 02$ & $\mathrm{DRB} 1 * 02$ & DQB $1 * 04$ & DQB1*04 & 8 \\
\hline PBMC 3 & $A * 22$ & $A * 34$ & $B * 17$ & $B * 50$ & DRB1*07 & $\mathrm{DRB} 1 * 02$ & DQB1*05 & DQB1*06 & 2010 \\
\hline UCBMC 3 & $A * 04$ & $A * 35$ & $B * 14$ & $B * 54$ & DRB $1 * 12$ & DRB $1 * 14$ & DQB $1 * 03$ & DQB1*09 & \\
\hline PBMC 4 & $A * 24$ & $A * 35$ & $B * 15$ & $B * 54$ & DRB $1 * 07$ & DRB $1 * 15$ & DQB $1 * 05$ & DQB1*09 & 3018 \\
\hline
\end{tabular}




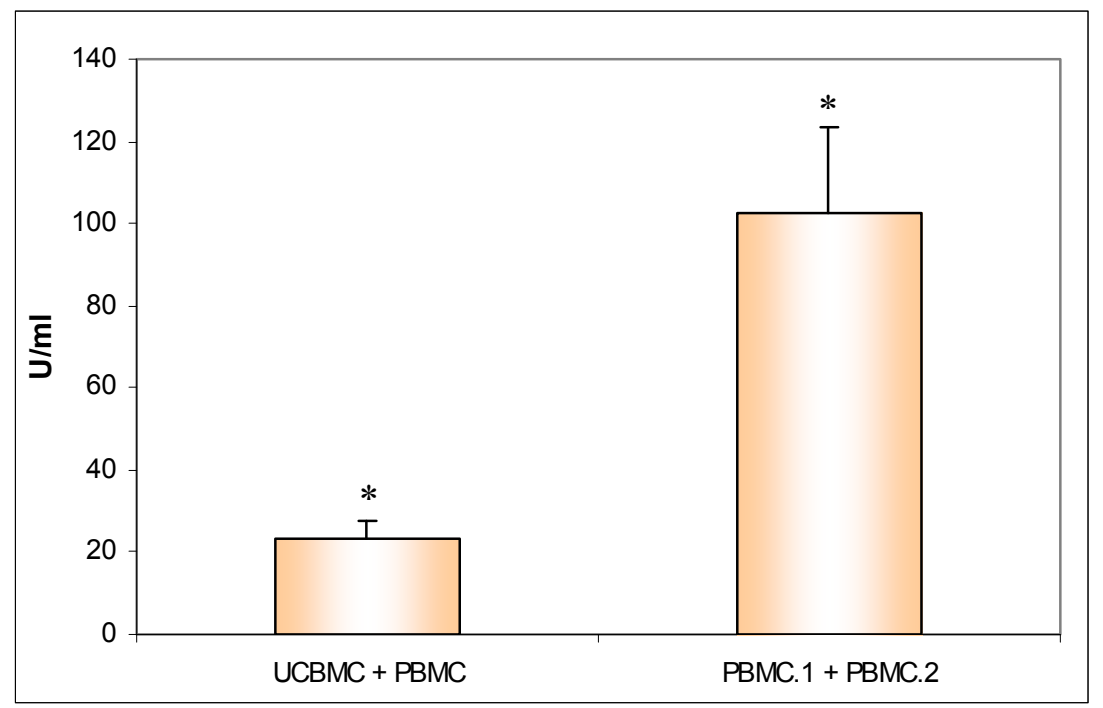

Figure 1. UCBMCs eliciting less allogenic stimulation compared to PBMCs counterpart in MLR assay ( $p$ value $<0.001$ ). Allogenic stimulation by PBMC was observed through high titer of IFN- $\gamma$ released in the supernatant.

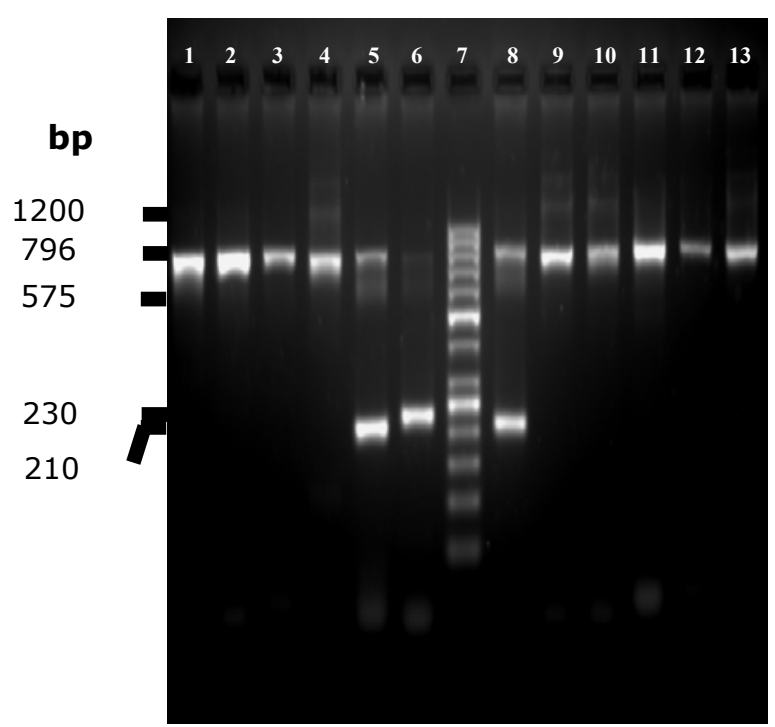

Figure 2. A typical gel image following PCR reaction for HLA type determination. This gel showed positive bands at lane 5 (220bp), lane 6 (240bp), and lane 8 (220bp) correspond positive PCR reactions for HLA-A*32, HLA-A*33, and $H L A-A * 32$ respectively. $780 \mathrm{bp}$ bands correspond to internal control bands indicating efficient PCR amplification. 
A

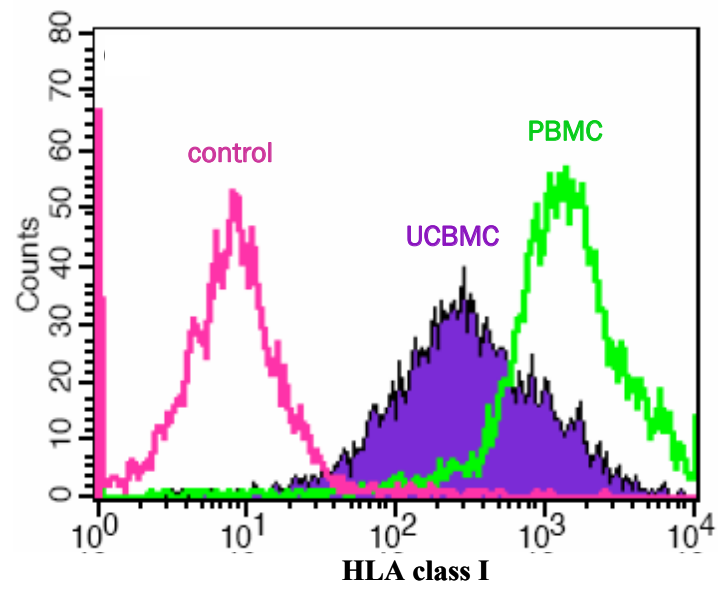

B

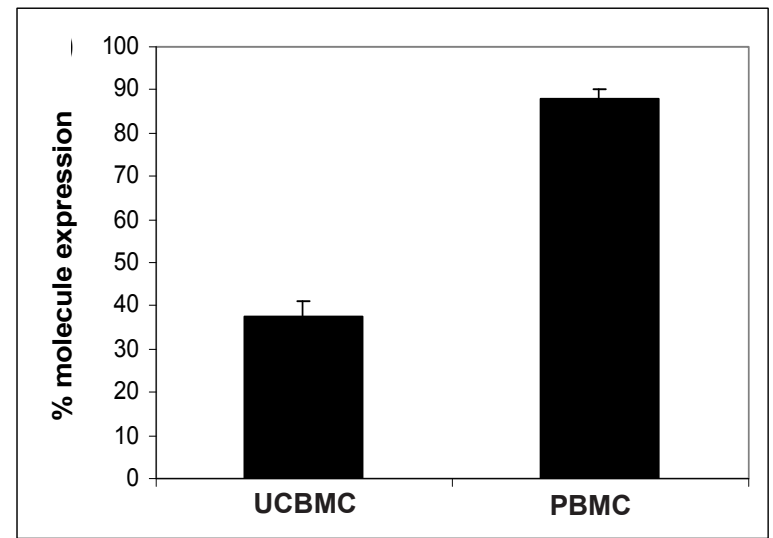

Figure 3. Flowcytometry analysis for HLA Class I expression on UCBMCs and PBMCs.

(A). The fluoresence intensity determines the degree of anti-HLA Class I bound to the cells and corresponds to the level of HLA class I molecule expression. PBMC showed a higher expression of HLA class I molecules compared to UCBMC. An unrelated antibody with the same isotype as the antibody used for HLA Class I and II (mIgG2a-PE) was used as a control to determine the background staining

(B). Percentage of HLA class I expression in UCBMCs compared to PBMCs (p value $<.001, n=6)$

A

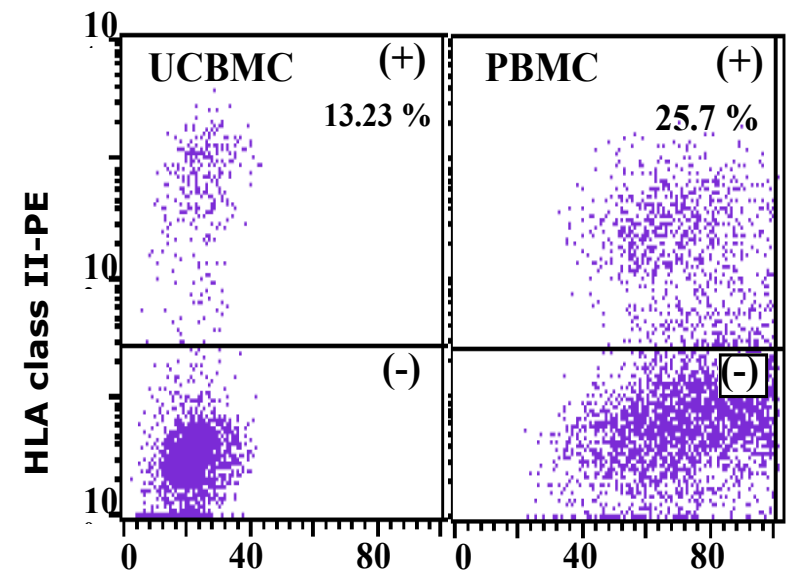

B

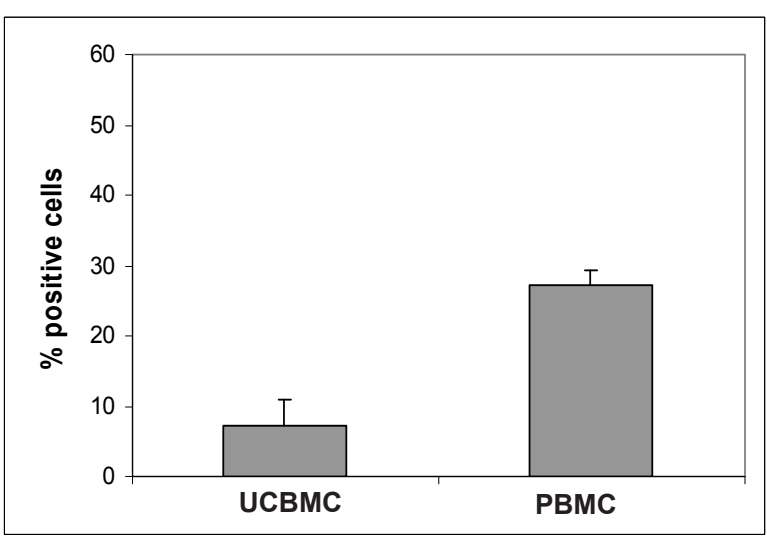

Figure 4. (A). A typical flowcytometry dot plot showing cell population expressing HLA class II molecule stained using anti-HLA class II-PE

(B). A summary of percentage cell population expressing HLA class II molecules on UCBMCs and PBMCs $(U C M C=7.20 \pm 4.32$, and $P B M C=27.14 \pm 7.54, p$-value $<.001, n=6)$. 


\section{DISCUSSION}

Stem cells have been shown to be potential cells that can be used in treatment for many diseases. The usage of hematopoetic stem cells isolated from umbilical cord blood has been adopted since the year 1980'started by the sucess of treatment a patitent with Fanconi's anemia. Within the last decade, the utilization of umbilical cord blood stem cells has extended beyond the treatment for hematological diseases and has been shown to potentially useful in the regeneration of injured tissue. Umbilical cord blood has shown its unique property through its low immunogenicity profile. This unique property has made mononucleated cells derived from UCB to become a potential candidate of medical option for a wider range of recipients with HLA-partial match. In term of the risk in the allogenic transplantation, UCBMNC have been reported to have a lesser extend of graft-versushost disease. ${ }^{18}$ The allogenic recognition is mediated through a communication between donor cells to the recipient cells via several molecules. Those molecules are including human leukocyte antigen (HLA) class I and class II to correspond with the recognition of foreign vs self antigen to $\mathrm{CD} 8^{+}$and $\mathrm{CD} 4^{+} \mathrm{T}$ cell respectively. Therefore, the levels of expression of HLA class I and II will determine the outcome of antigen recognition by $\mathrm{T}$ cells. HLA molecules are expressed on cell surfaces normally contain bound peptides. The peptides bound to allogeneic HLA molecules may play several roles in the recognition of these molecules. HLA class I molecules present in all nucleated cell, while HLA class II molecules generally expressed on professional antigen-presenting cell. UCBMC was shown to express HLA class I antigen however lower than PBMC (Fig. 3 ) and UCBMC had less cells expressing HLA class II molecules compared to PBMC (Fig. 4).

Mixed lymphocyte reaction (MLR) is an assay to detect response of alloreactive T cells to foreign HLA molecules and used as a predictive test of $\mathrm{T}$ cellmediated graft rejection. ${ }^{19}$ MLR was performed by culturing mononuclear leukocytes ( $\mathrm{T}$ cells, B cells, NK cells, mononuclear phagocytes, and dendritic cells) from one individual with mononuclear leukocytes from another individual ${ }^{19}$. In this experiment, PBMC acted as recipient's cells which reacted against PBMC or UCBMC from donors from another individual, resulting in activating $\mathrm{T}$ cell into effector $\mathrm{T}$ cell. The allogenic reaction was monitored through the occurence of proinflammatory cytokine secretion, such as secretion of Interferon- . Co-culture of UCBMNC with recipient's
PBMNC in the MLR assay shown less released IFN $\gamma$ compared than MLR of PBMC isolated from recipient and donor. The less allogenic reaction observed in the MLR assay may be due to the lack of HLA expression of both HLA class I and less cells with HLA class II.

To confirm that the donor and recipient have limited degrees of matched HLA types, HLA typing was conducted on all donor and recipient cells used in this study. It was found that between the donor and the recipient of HLA type matched were merely within 1-3 out of 8 or 4 paired allelles examined (HLA-A, HLAB, HLA-DRB1, and HLA-DQB1). This confirmed that despite the differences in the HLA type, the allogenicity of UCBMNC was minimal as observed in the less IFN- secretion in the MLR assay.

In conclusion, umbilical cord blood has been gaining vast attention as an alternative source of transplantable stem cells replacing bone marrow and peripheral blood due to its low immunogenicity profile. The utilization of UCBMCs has been extended towards the treatment for hematological diseases. Findings obtained from this study confirms UCBMCs' low immunogenicity along with its feasibility and efficacy to be used in allogeneic transplantation. Whilst allogeneic cell stimulation is mediated via recognition of self antigen through the HLA molecule, the expression levels and cell composition of UCBMCs were compared to PBMCs using flowcytometry. It was found that UCBMCs expressed less HLA Class I molecule, with less cells expressing HLA Class II. This finding is in accordance to the less capability for non-self antigen presentation by UCBMCs towards recipient's immune system. Accordingly, UCBMCs shown to be less competent in inducing allogeneic stimulation as shown by low IFN $\gamma$ secretion in MLR assay.

\section{REFERENCES}

1. La Nasa G, Giardini C, Locatelli F, Argiolu F, Vassallo E, Prete A, et al. Unrelated bone marrow transplantation in thalassemia. The experience of the Italian Bone Marrow Transplantation Group (GITMO). Haematol. 2002;87:5861.

2. Cheng CN, Lu CC, Sun HF, Su WC, Chen JS. Successful matched-unrelated bone marrow transplantation in a patient with beta thalassemia major. J Pediatr Hematol Oncol. 2002;24(7):579-81.

3. Bleakley M, Shaw PJ, Nielsen JM. Allogeneic bone marrow transplantation for childhood relapsed acute lymphoblastic leukemia: comparison of outcome in patients with and 
without a matched family donor. Bone Marrow Transplant 2002;30(1):1-7.

4. Burt RK, Loh Y, Pearce W, Beohar N, Barr WG, Craig R, et al. Clinical applications of blood-derived stem cells for nonmalignant diseases. JAMA. 2008;299(8):925-936.

5. Broxmeyer HE, Srour E, Orschell C, Ingram DA, Cooper S, Plett PA, etal. Cord blood stem and progenitor cells. Methods in Enzymology 2006;49(18):439-473.

6. Voltarelli JC, Couri CE, Stracieri AB, Oliveira MC, Moraes DA, Pieroni F, et al. Autologous Nonmyeloablative Hematopoietic Stem Cell Transplantation in Newly Diagnosed Type 1 Diabetes Mellitus. JAMA. 2007; 297(14):1568-76.

7. Gluckman E, Broxmeyer H, Auerbach A. Hematopoietic reconstitution in a patient with Fanconi's anaemia by means of umbilical cord blood from an HLA identical sibling. Engl J Med. 1989;321:1174-8.

8. de Wynter EA, Testa NG. Interest of cord blood stem cells. Biomed Pharmacother, 2001;55:195-200.

9. van de Ven C, Collins D, Bradley MB, Morris E, Cairo MS. The potential of umbilical cord blood multipotent stem cells for nonhematopoietic tissue and cell regeneration. Exp Haematol. 2007;35:1753-65

10. Rocha V, Wagner JE Jr, Sobocinski KA, Klein JP, Zhang MJ, Horowitz MM, et al. Graft-versus-host disease in children who have received a cord blood or bone marrow transplant from an HLA-identical sibling. Eurocord and International Bone Marrow Transplant Registry Working Committee on Alternative Donor and Stem Cell Sources. N Engl J Med. 2000;342(25):1846-54.
11. Fasouliotis SJ, Schenker JG. Human umbilical cord blood banking and transplantation: a state of the art. Eur J Obstet Gynecol Reprod Biol. 2000;90(1):13-25.

12. Moise KJ. Umbilical cord stem cells. Obstet Gynecol. 2005;106(6):1393-407.

13. Rubinstein P. Why cord blood? Hum Immunol. 2006; 67(6):398-404.

14. Bradley MB, Cairo MS. Cord blood immunology and stem cell transplantation. Hum Immunol. 2005;66(5):431-46.

15. Laughlin MJ, Eapen M, Rubinstein P, Wagner JE, Zhang MJ, Champlin RE, etal. Outcomes after transplantation of cord blood or bone marrow from unrelated donors in adults with leukemia. N Engl J Med. 2004;351(22):2265-75.

16. Laughlin MJ, Barker J, Bambach B, Koc ON, Rizzieri DA, Wagner JE, etal. Hematopoietic engraftment and survival in adult recipients of umbilical-cord blood from unrelated donors. N Engl J Med. 2001; 344(24):1815-22.

17. Riordan NH, Chan K, Marleau AM, Ichim TE. Cord blood in regenerative medicine: do we need immune suppression? J Transl Med. 2007;5-8.

18. Wagner JE, Barker JN, DeFor TE. Transplantation of unrelated donor umbilical cord blood in 102 patients with malignant and non-malignant disease: influence of CD34 dose and HLA disparity on treatment-related mortality and survival. Blood. 2002;100:1611-1618.

19. Slavcev A, Striz I, Ivaskova, E and Breur-Vriesendorp BS. Alloresponses of Cord Blood Cells in Primary Mixed Lymphocyte Cultures. Hum Immunol. 2002;63:155-63. 